\title{
MEDIA CULTURE
}

DOI:

\section{POLYCODE PHENOMENON OF THE NEWS TEXT IN ONLINE MEDIA}

\author{
Alevtina A. Kolosova \\ Candidate of Historical Sciences, Associate Professor \\ Peoples' Friendship University of Russia \\ (Moscow, Russia) \\ e-mail: Kolosova-aa@,rudn.ru \\ Natalia V. Poplavskaya \\ PhD in Philology, lecturer \\ Peoples' Friendship University of Russia \\ (Moscow, Russia) \\ e-mail: Poplavskaya-nv@,rudn.ru
}

\begin{abstract}
The active introduction of the latest technologies in the field of mass communication has led to new approaches to the creation and analysis of news texts in online media. Until recently, the informational function of news media texts was considered to be the main one. However, due to the growing role of non-verbal means in informational messages and the use of a multimedia language - graphics, color, photographs, drawings, various audio-visual elements - the impact function is becoming the dominant onein integrated, or so called polycode news texts.
\end{abstract}

Keywords: polycode phenomenon, online media, news text, media discourse

\section{ПОЛИКОДОВОСТЬ НОВОСТНОГО ТЕКСТА В ИНТЕРНЕТ-СМИ}

\author{
Алевтина Александровна Колосова \\ Кандидат исторических наук, доцент \\ Российский университет дружбы народов \\ (Москва, Россия) \\ e-mail:Kolosova-aa@rudn.ru \\ Наталия Владимировна Поплавская \\ Кандидат филологических наук, лектор \\ Российский университет дружбы народов \\ (Москва, Россия) \\ e-mail: Poplavskaya-nv@,rudn.ru
}

\begin{abstract}
Аннотация.Активное внедрение новейших технологий в сферу массовой коммуникации обусловило новые подходы к созданию и анализу новостных текстов интернет-СМИ. До недавнего времени основной функцией новостных медиатекстов считалась информационная. Однако в интегрированных, или поликодовых, новостных текстах, на первое место все чаще выходит функция воздействия, обусловленная растущей ролью невербальных средств в информационных сообщениях и использованием мультимедийного языка - графики, цвета, фотографий, рисунков, различных аудиовизуальных элементов.
\end{abstract}

Ключевые слова: поликодовость, интернет-СМИ, новостной текст, медиадискурс

News online texts in the structure of news journalism. Today, news journalism occupies one of the leading places in the structure of Russian and foreign journalism. There are special curricula on the subject of 'News Journalism' in a number of Russian universities, e.g. Murmansk State University for the Humanities, Tver State University, Neftekamsk branch of Bashkir State University (Kim 2005).

A. Amzin proposes to consider news journalism 'the art of efficient transmission, processing and publication of information.' The news in the vast majority of cases is fact journalism. 'It is strictly forbidden for a news journalist to explicitly express in the text his attitude to the actors, as well as to creatively rethink the available data...' (Amzin 2011).

A significant proportion of news media texts are online or Internet news journalism. 
This kind of journalism is seen as journalism created exclusively for the world wide web. According to Mark Deuze, 'online journalism can be functionally differentiated from other kinds of journalism by using its technological component as a determining factor in terms of a (operational) definition' (Deuze 2003).

The peculiarity of online journalism is that it can provide general information for all users and specialized information for a specific audience as well.

'News discourse is an essential component of mass media discourse and is a collection of texts operating in the field of news broadcasting, taken in the unity of all linguistic and extralinguistic characteristics associated with their production, distribution and perception' (Dobrosklonskaya 2016).

There are different types of online news journalism:

1) Mainstream news sites;

2) Index and categoring sites;

3) Meta - and comment sites;

4) shareanddiscussionsites. (Deuze 2003)

Examples of sites of the first type are CNN, BBC, and MSNBC. Most online newspapers may fall into this category. This type of news site 'does not differ much from print or broadcasting journalism in its approach to journalistic storytelling, news values, and relationships with audiences' (Deuze 2003).

The sites of the second category offer catalogs of news agencies, thematic collections, discussion and exchange of news.

Meta- and comment sitesare 'sites about newsmedia and media issues in general; sometimes intended as media watchdogs' (Deuze 2003).

Discussion sites satisfy the need of people to communicate with each other. 'This type of online journalism has also been described as 'group weblogs' (Deuze 2003).

'All four types of news sites can be considered to belong to a professional domain of journalism, as the function of (most of) these sites is still the same as the main purpose of journalism... to provide citizens with the information that they need ...' (Deuze 2003).

Analysis of news texts. Internet news texts attract the attention of both Russian and foreign scholars working in such fields as linguistics, journalism, semiotics, communication, communication theory, and online media.

Difficulties in analyzing media texts of news media are related to the fact that news journalism in Russian and foreign media discourses is represented by different genres that do not always coincide in form and genre characteristics.

In foreign media linguistics, 'news' represents a separate genre, so-called news genre of journalism.

This kind of genre (news media texts) occupies the first place in the framework of media linguistics, followed by comment and analysis, features and advertising (Dobrosklonskaya 2016).

In recent years, Russian scholars tend to single out the news genre separately. (Repkova 2011; Kolesnichenko 2008 and others). However, earlier, three large groups of media genres were used to single out: informational (note, reportage, report, interview);information and analytical ones and informationand journalistic (Grabelnikov 2005: Tertychniy, 2000).

In the Anglo-American tradition, news genres are divided into sub-genres, including such ones as news report, the news interview, or the news headline (Montgomery 2007). M. Montgomery defines news as information about current or recent events, happenings or changes taking place outside the immediate purview of the audience and which is considered to be of likely interest or concern to them' (Montgomery, 2007). He writes, 'not every event or piece ofinformation counts as news' (Montgomery 2007). Events become news only if they meet one or more criteria of 'news value':recency/timeliness, intensity/discontinuity, scale/scope, conflict, personalization,power, negativity, unexpectedness, consonance, proximity/cultural relevance, meaningfulness/unambiguity, composition/fit, the epistemological status of news values, broadcasting standards, the regulation of broadcast news.

Russian researchers call approximately similar criteria for selecting news. (Karpushin and Chikirova 2007).

Thus, both Russian and foreign experts in the field of journalism and research of media texts rightly note that the event can become informational news if it fits into the set of the following media topics: environmental disasters, scandals, elections, disasters and accidents, wars, summits, glamor, need, sporting events, events of human interest, etc.

In recent years, in connection with the transformation of the Russian media system and the adoption of the information standards of British and American journalism, in Russian journalism one can observe a clearer division of texts into purely 'news' and texts of 'journalism of opinions'. The number of the latter hassignificantly reduced. (Vartanova 2013).

Modern online news media texts form a linguistic, cultural and informational (media) picture of the world of the addressee, in which both the explicit and implicit levels manifest the ideological orientation of the information presented. Especially vivid ideological modality is manifested in polycode (multicode) news texts.

Polycode phenomenon of mediatexts. In Russian linguistics, the term 'polycode' began to be used relatively recently. This term describes different kinds of texts that consist verbal and non-verbal information. 'Polycode text coherence appears in verbal and non-verbal components' coordination, and presents in substantial, lingual, compositional levels'(Berest 2016).

News media texts in online media are classified as creolized texts, which in linguistics are understood as texts, 'the texture of which consists of two non-homogeneous parts: verbal (language /speech) and non-verbal (belonging to other sign systems than natural language)' (Sorokin, 1990). 
Along with the terms 'multicode' and 'creolized', in domestic linguistics they use such synonyms as, 'multimodal', 'polymodal', 'multimedia', 'verbal-visual', semiotically complicated texts, etc.

In the English-language scientific literature, one can find the terms 'combined', 'creolized', 'multimodal', 'semiotically complicated texts'. (Deuze 2004; Kress 2010; Makaruk 2015).

Media text in online media can be represented as 'a combination of verbal, non-verbal components and acquired special network properties' (Shesterkina 2013).

In the article 'The Specificity of Modern Media Text'M.Yu. Kazak, doctor of philological sciences, professor of the journalism department of the National Research University 'BelSU', discussing the essential features of media text, writes that 'modern textual reality, without canceling traditional theories, requires integrative interpretations that can explain new aspects or new types of texts of mass communication - mixed, creolized, multicode, hypertexts, multimedia texts, the essential characteristics of which are associated with the development of information technology and the convergence of mass media. (Kazak 2012).

The polycodephenomenon of media text is among the leading signs of media text. (Kazak, 2012). 'The current generation of people is already accustomed to the 'text of three dimensions', to receive information in the fusion of sound, speech, image ...' (Duskaeva 2011).

As E. Solntseva noted, 'polycode phenomenon is especially relevant for Internet texts, as the web space provides the widest possibilities for combining various elements in publications. In the media discourse the actual text of the article, photos, hyperlinks to video or audio fragments, advertisements, as well as hyperlinks to other resources ... are becoming the polycode elements' (Solntseva 2018).

The key features of media text in online media both foreign and domestic linguists call intertextuality (hypertextuality), multimedia, and interactivity.

According to M. Deuze, one of the ways of defining multimedia in journalism is 'the presentation of a news story package on a website using two or more media formats, such as (but not limited to) spoken and written word, music, moving and still images, graphic animations, including interactive and hypertextual elements...' (Deuze 2004).

It is very important to pay attention to one more peculiarity of news online texts. The matter is that Internet texts are stepwise. News text does not appear in its entirety. First, the user of the Internet site sees only the headline. Then everything depends on his interest in reading the entire text and choosing the reading option: whether to start with a photograph, or hyperlink to another source of information. Thus, the problem of studying the compositional and stylistic features of Internet media text naturally arises. (Shesterkinaand Lobodenko 2013).

Paraphrasing the recommendations of A. Amzin on creating the design of good news, let's outline the features of good online news:

1. An interesting news item and a good headline.

2. The message is of interest on first reading.

3. Competent text structuring.

4. The ability of the reader to check the sources (additional links and useful hints; hyperlinks.

5. Short sentences.

6. A minimum of introductory words and turns. (Amzin 2011).

The active introduction of the latest technologies in the field of mass communication determined fundamental differences of online media texts from traditional print and even television version. The verbal information in the media text of online media is often supplemented by infographics, sound, video, animation, which allows you to achieve the greatest emotional effect and have significant media impact on the audience.

The impact of news texts. According to Russian researchers, there is always a certain ideological modality in media texts, which some authors call the rhetorical modality of the media text (Annenkova, 2010); subjective modality or discursive modality (Klushina 2012).

The ideological components of interpretation are realized using a wide range of means of both verbal and audiovisual series, which form a certain attitude to the events and personalities being covered. (Dobrosklonskaya, 2016).

Previously, news was defined as 'reliable, neutral and current factual information that is important and valuable for citizens' (Montgomery 2007), but recently in the language of news media texts there are more emotionally colored rather than neutral phrases, such as it was before. This coloration often has a negative connotation. For example, in the plots about the Crimea and Russia reunion, the USA media most frequently use lexemes and phrases such as 'illegal voting in the Crimea'; 'intervention'; 'Russian invasion of Crimea'; 'Occupation of Crimea', 'annexation of Crimea'. (Fox News, CNN).On the pages of many Western European newspapers, stereotypical ideas about Russia are gaining new life: 'strong Russian bear grip', 'furious Kremlin', 'pressure from the Kremlin', 'paws of the Kremlin'('The Guardian'). The negative image of Russia in the international arena is created by the following lexical means: 'Kremlin paws'; 'Middle Ages'; 'Return to Stalinism'; 'Aggressive pressure from Russia' ('The New York Times'); 'Economic pressure of Russia'; 'Aggressive politics'; 'Belligerent disposition of Russia; 'Eternal' gas 'blackmail'; 'Putin's tough diplomacy'; 'Imperial ambitions' ('The Independent'). Even in the texts of the Air Force, which positions itself as the most objective source of information, one can find such phrases as: 'pressure from Russia'; 'Russian intervention', 'pressure and blackmail', 'aggressive Russian strategy', 'Moscow pressure on Ukraine' and others.

Unfortunately, the cognitive function of news (gaining knowledge), which Theun Van Dyck considered the main, is not the main any more.(Van Dijk 2013). 
Currently, the information function of news media texts is often inferior to the influencing one: 'in the news, the acting function is the main one' (Negryshev 2009).

CONCLUSION. This paper covers some current uses of the term 'polycode media text' and its synonyms in the framework of online news media text research both in Russia and foreign linguistics. Hypertextuality, multimedia and interactivity are considered to be the key differences between online media and traditional ones.

The polycodephenomenonof news Internet texts is already evident at the heading level. The fact is that in the Internet media the form often carries a semantic load. Due to the visualization of news media texts - infographics, all kinds of collages, drawings, photographs, videos, their impact on the audience is significantly increasing.

\section{LIST OF REFERENCES}

Amzin A. (2011) Novostnaia internet zhurnalistika [News Internet journalism]. M. AspektPress, 144 s. S.26

Annenkova I.V. (2010) Mediadiskurs $\mathrm{v}$ fokuseritoriki [Media discourse in the focus of neo rhetoric]. Jurnalistica $\mathrm{i}$ mediaobrazovanie: Sb. tr. IV Mezhdunarodnoinauchno-prakticheskoykonferencii/ pod red. prof. A.P. Korochensko

Berest V. Conceptual Artwork as a PolycodeText .VestnikRossiiskogouniversitetadruzhbynarodov. Seriia: Voprosyobrazovaniia: iazyki i spetsial'nost'. 2016, vyp. 3, p. 124-129. https://cyberleninka.ru/article/n/conceptual-artwork-as-a-polycode-text).

Grabelnikov A.A. (2005).Rabotajurnalista v gazete: uchebnoeposobie [Work of a journalist in the press: training guide]. Moskva: RIP Holding. $274 \mathrm{~s}$.

Deuze M. (2003). The Web and its Journalisms: Considering the Consequences of Different Types of News Media Online. NewMedia\&Society 5(2), pp. 203-230

Deuze M. (2004). What is Multimedia Journalism? Journalism Studies, Volume 5, Number 2, pp. 139-152

Dobrosklonskaya T.G. (2016) Novostnoidiskurskakob'ectmedialingvisticheskogoanaliza [Media discourse as an object of linguistic analysis]. Diskurssovremennihmass-media $\mathrm{v}$ perspective teorii, socialnoipraktiki I obrazovaniya: II mezhdunarodnoprakticheskayakonferenciyaaktualniye problem sovremennoimedialingvistiki I mediakritiki v Rossii I zarubejom: II mezhdunarodniynauchniy seminar. Belgorod: BelGu, 13-21.

Duskaeva L.R. (2011). Mediastilistika v Rossii: traditsii i perspektivy [Media stylistics in Russia: traditions and prospectives]. ZHurnalistika i kulturarusskoirechi, (2), 7-25

Kazak M. IU. (2012). Spetsifikasovremennogomediateksta [Specifics of modern media text], Vol. (1), S. 30-41 http://discourseanalysis.org/ada6/st42.shtml

Karpushin D., CHikirova S. (2007). Press- reliz. Pravilasostavleniia [News letter. Rules of preparation]. SPbPiter: 224 s, S. 306

Kim M.N. (2005) Novostnaiazhurnalistika. Bazovyikurs. Uchebnik [News journalism. Basic course. Textbook]. SPb.: IzdvoMikhailova V.A. 2005, 352s.

Klushina N. I. (2013). Osnovnyetipysovremennogomediadiskursa [Main types of modern media discourse]. Rechevoeobshchenie. SpetsVestn. Krasnoiarsk, http://ecoling.sfu-kras.ru/wp-content/uploads/2013/12/2012.-Вып.-14-22.pdf

Kolesnichenko A. V. (2008). Prakticheskaiazhurnalistika. Uchebnoeposobie [Practical journalism. Training guide]. M: IzdvoMoskUn-ta 2008

Kress G. (2010). Multimodality: Exploring Contemporary Methods of Communication. London: Routledge, 2010. 236 p.

Makaruk L. Linguistik. (2015). Approaches to the Study of Multimodal Texts. Within Language, Beyond Theories (Volume III): Discourse Analysis, Pragmatics and Corpus-based Studies. Ed. Malec W., Rusinek M. CambridgeScholarsPublishing, P. 26-36.

Montgomery M. (2007). Discourse of Broadcast News. A linguistic approach. Routledge, 2007. 246p, pp. 25-26.

Negryshev A.A. (2009). Aspektyrechevogovozdeistviia v novostiakh SMI: Uchebnoeposobie Aspects of verbal influence in news of mass media]. Vladimir: VGGU, 144 s. S. 6

Repkova T. (2001). Novoevremia: kakizdavatprofessionalnuiugazetu v demokraticheskomobshchestve [News time: how to publish a professional newspaper in a democratic society]. M.: GIPP, S. 133

SHesterkina L.P., Lobodenko L. K. (2013). Bazovyepodkhody k sozdaniiuuniversalnogomediateksta v Internet-SMI [Basic approaches for creating universal media text in Internet media]. VestnikIUzhno-Uralskogogosudarstvennogouniversiteta .Seriia: Lingvistika. Vypusk 2, tom 10. http cyberleninkaru article $\mathrm{n}$ bazovye-podhody-k-sozdaniyu-universalnogo-mediateksta-v-internet-sm Solntseva E. S. (2018). Relevantnostelementovpolikodovogoteksta [The relevance of the elements of the polycode text]. Litera, S. 7784. http://e-notabene.ru/fil/article_25194.html

Sorokin U. A. (1990). Kreolizovannyeteksty i ikhkommunikativnaiafunktsiia [Creolised texts and their communicative function]. U. A. Sorokin, E. F. Tarasov Optimizatsiiarechevogovozdeistviia. M.: Nauka, $240 \mathrm{~s}$.

Tertychnyi A.A. (2000). ZHanryperiodicheskoipechati: Uchebnoeposobie [Genres of periodical press: training guide]. M.: AspektPress, $310 \mathrm{~s}$.

Textbook, Murmansk State University. http://www.mshu.edu.ru/umuumk

Textbook on news journalism, Tver State University http://edc.tversu.ru/f/ff/spec/030601/opdv3502.pdf

Textbook on news journalism, Neftekamsk branch of Bashkir State University http://www.studfiles.ru/preview/3912359/

Van Dijk T. A. (2013) PompeuFabra University, Barcelona, www.discourses.org Epistemic News Discourse Analysis c. 10-12.

Vartanova E.L. (2013). Constructing Russian Media System in the Context of Globalization. World of Media. Yearbook of Russian Media and Journalism Studies. Moscow: Mediamir, p. 30.

\section{For citation:}

Kolosova, A.A. \& Poplavskaya, N.V. (2019) POLYCODE PHENOMENON OF THE NEWS TEXT IN ONLINE. International Scientific-Pedagogical Organization of Philologists “WEST-EAST ” (ISPOP). Scientific Journal WEST-EAST. Vol 1/1 N1 (October, 2019). pp. 66-70. doi:

\section{Для цитирования:}

Колосова, А.А., Поплавская, Н.В. (2019) MEDIA ПОЛИКОДОВОСТЬ НОВОСТНОГО ТЕКСТА В ИНТЕРНЕТ-СМИ // International Scientific-Pedagogical Organization of Philologists “WEST-EAST” (ISPOP) . Scientific Journal WEST-EAST. Vol 1/1 N1 (October, 2019). C. 66-70. doi: 
Information about the authors: Alevtina A. Kolosova - PhD in history, associate professor of Mass Communication Department of Peoples' Friendship University of Russia

e-mail:Kolosova-aa@,rudn.ru

Information about the authors: Natalia V. Poplavskaya - PhD in Philology, lecturer of Mass Communication Department of Peoples' Friendship University of Russia, Deputy Dean for International Relations, Philological Faculty

e-mail:Poplavskaya-nv@rudn.ru

Сведения об авторах: Колосова А.А. - доктор исторических наук, ассоциированный профессор департамента массовых коммуникаций Российского университета дружбы народов, РФ. Москва, Россия.

e-mail:olosova-aa@rudn.ru

Сведения об авторах: Поплавская Н.В. - доктор филологии, лектор департамента массовых коммуникаций Российского университета дружбы народов, РФ. Москва, Россия.

e-mail:Poplavskaya-nv@rudn.ru

DOI:

\title{
CINEMA AND FILM CRITIC: MEDIAPRACTICS IN DISCOVERING OF THE MEAN DOMINANT
}

\author{
Ludmila Sayenkova-Melnitskaya \\ Candidat of Philological Sciences, Associate Professor \\ Belorussian State University \\ (Minsk, Belarus) \\ e-mail: sayenkova@gmail.com
}

\begin{abstract}
Since its inception, cinema has been one of the most popular forms of art, which, on the one hand, captures, and on the other hand, affects the formation of socio-cultural codes.Simultaneously with the appearance of film originated and film critics, which in itself is a unique fact in the history of art.The cultural significance of film criticism as a special kind of creative activity is determined. Different variants in the presentation of cinema art, formed in different historical periods, are analyzed.Different types of discursive practices of film criticism manifested in the media are considered. The attention is focused on the fact that the most important purpose of film criticism is the representation of value meanings imprinted in the work of cinema.The method of comparative and system-integral analysis reveals the facts of discrepancy between the meanings of screen works and the author's intentions, which are reflected in the critical texts.
\end{abstract}

Keywords. Cinema, film criticism, media, analysis, senses

\section{КИНО И КИНОКРИТИКА: МЕДИАПРАКТИКИ В РАСКРЫТИ СМЫСЛОВЫХ ДОМИНАНТ}

\author{
Людмила Саенкова-Мельницкая \\ Кандидат филологических наук, доцент \\ Белорусский государственный университет \\ (Минск, Беларусь) \\ e-mail: sayenkova@gmail.com
}

\begin{abstract}
Аннотация. С момента своего появления кино является одним из наиболее востребованных видов искусства, которое, с одной стороны, запечатлевает, а с другой стороны, влияет на формирование социокультурных кодов. Одновременно с возникновением кино возникла и кинокритика, что само по себе является уникальным фактом в истории искусства. Определяется культурологическая значимость кинокритики как особого вида творческой деятельности.Анализируются вариативные подходы в презентации киноискусства, сложившиеся в разные исторические периоды. Рассматриваются разные виды дискурсивных практик кинокритики, проявившихся в медиасреде. Акцентируется внимание на том, что самым главным предназначением кинокритики является представление ценностных смыслов, запечатленных в произведении киноискусства. Методом сопоставительного и системно-целостного анализа раскрываются факты несоответствия смыслов экранных произведений авторским интенциям, запечатленным в кинокритических текстах.
\end{abstract}

Ключевые слова. Кино, кинокритика, медиасреда, анализ, смыслы

ВВЕДЕНИЕ. Кинокритика возникла одновременно с показом первых фильмов, что в истории искусства является беспрецедентным фактом. Восторженные анонсы, сопровождавшие первые сеансы и запечатлевшие радость узнавания реальной действительности, зафиксировали гедонистический период в развитии кинокритики. С приобретением кино своего языка, постепенным развитием и усложнением художественной образности экранного зрелища от кинокритики потребовалось не просто выразить удивление от того, как, 